\title{
Corruption, Policing and Migration: Exploring the Interaction Between Migrant Workers and Police in Russia, Ukraine and the UK
}

\author{
Anna Markovska*, Alexey Serdyuk** (iD and Valerii Sokurenko** (iD
}

\begin{abstract}
The rights of migrant workers and their experiences in host countries have been high on the political agendas of Europe and beyond. This article uses data from 138 semi-structured interviews conducted with migrant workers in the UK, Russia and Ukraine to study their relationships with the police in host countries. We aim to contribute to the literature on policing and migration by analysing three different host countries, and the experience of temporary migrant workers regarding policing within each country. We suggest that the interplay between the experiences of policing in home and host countries can provide important insights into the practicalities of policing, but should not be considered apart from the context of the ethnic origin of migrant workers.
\end{abstract}

\section{INTRODUCTION}

This article explores the experiences of migrant workers in host countries (the countries of destination) and more specifically, their experience of policing. One Moscow-based Ukrainian migrant worker gave the following account:

June $12^{\text {th }}$, 2011, Moscow: "On the way home from work at around 11 pm I came across two policemen. First, they hesitate a little, then they approached me and asked to present my documents. I show my Ukrainian passport and my migration card (I have received my migration card at the border crossing point).

They (police) say, "You can buy this paper [migration card] for 50 roubles at any train station".

"But this is not my problem," I reply.

They say, "Ok, but you will have to follow us to the police station for the document check."

Thinking about my early start the following morning, and also the fact that visiting a police station is rather dangerous, I reply, "My documents are all legal, but here we go, take 100 roubles and I will go". I open the notebook where I keep small cash, I have 110 roubles (from years of experience, I know that it is important to separate the cash for police from the cash in my purse).

\footnotetext{
* Anglia Ruskin University, Cambrige, UK

** Kharkiv National University of Internal Affairs
} 
They, "What, 100 roubles only?! Do you know how big the fines are these days?"

I reply, "What fines?! All my documents are in order, this is just so I don't have to go to your station."

They, "Ok then, only out of respect to your age", and they take the 110 roubles, all that they can see."

From the Diary of a 65 years old Ukrainian migrant worker in Moscow.

This quote is representative of the daily experience of migrant workers in different parts of the world. From South Africa to Ukraine and in Russia, migrant workers often present a highly visible and vulnerable group. This issue is not new. Melossi (2015) analysed European and American approaches to dealing with migration and migrant workers and argued that the way these groups are perceived in society depends "on the receiving norms and practices of the countries where they are admitted" (p.87). It is often the case that excessive policing of migrant groups is supported by populist thinking about migrant workers as "undeserving others". The socio-cultural context of the host country is as important to study as socio-cultural heritage of the communities of migrant workers. Light (2010) discusses the ways migration policies are enforced in the city of Moscow and distinguishes between "violation of the law by officials to secure private financial gains (that is, corruption) and the targeting of particular individuals for differential treatment based on ethnic origins (that is, ethnic discrimination)" (p. 293). Understanding the convergence of migration policies and policing will inform an understanding of the street policing experience of some vulnerable groups.

The project was originally proposed in 2010 with the aim of understanding the experience of crime and policing among Ukrainian migrant workers in the UK and in Russia, but was later developed to consider three distinct groups of migrant workers in three different settings. This article is based on 138 interviews with migrant workers conducted in three countries: the UK, Russia and Ukraine in the summer of 2011. We begin with a brief overview of the politics of migration, moving on to discuss the experience of policing by migrant workers in host and home countries.

\section{POLICING MIGRANT WORKERS}

Police corruption can be discovered in any country. However in some countries, such as Russia and Ukraine, corruption within the police force may be considered as part of the system of governance. Light (2010) argues that in Russia, and specifically in Moscow, "police interact with the civilian political authorities in the actual implementation of particular policies to produce outcomes - enforcement- that may be illegal or extra-legal" (Light, 2010, p. 277). Police corruption in post-Soviet countries has been presented as a legacy of the Soviet past (Shelley, 1990), resulting in impoverished, unresponsive and powerful social institutions that are on a mission to find new ways of exercising control (Beck and Chistyakova, 2002; McCarthy, 2013; Friesendorf, 2017). Beck and Chistyakova (2002) report on the study of policing in the city of Kharkiv, Ukraine, where the public perceived the police "as a powerful group using its authority for its own end, and able to violate the law if they need to do so" (p.130). This particular style of policing is labelled "predatory policing" (Light, 2010).

Light (2010) argues that the best way to understand policing in the Post-Soviet realm is to study police interaction with the authorities. While analysing Moscow's migration control and enforcement, Light (2010) notices that "police corruption is shaped by the intersection between the private interests of the police and the political agenda of their masters" (p.277). In this sense, police simply respond to initiatives from "their political masters" (Ibid.). The messages of these political masters are often one-sided, presenting migrant populations as essentially criminal and "undeserving others". 
Beck and Lee (2002) discuss the following three opportunities for police officers to act corruptly: the use of discretion; the lack of an effective anti-corruption institutional framework; and the public acceptance of corrupt policing. The use of discretion by police officers has been the subject of debate in many countries, but the effectiveness of anti-corruption campaigns, and the public attitude towards corruption, have been major concerns of countries in transition. In the UK policing different ethnic communities has been a subject of intense debate (Junger, 1990; Bowling, Parmar, Phillips, 2003). It has been recognized that different ethnic groups have very different experiences of policing, with a disproportionate use of stop and search powers targeting certain ethnic groups (Bowling, Parmar, Phillips, 2003). Light (2010) demonstrated in his Moscow study that police misconduct and corruption are often "sanctioned" by the prevailing political agenda. So, a loose definition of police discretion can be heavily exploited and is open to specific interpretation. Light (2010) considers the police in Moscow to be an agent of political power that is tasked with "limiting legal residence and harassing migrants", and thus they cannot be simply viewed as "self-interested parties pursuing their own enrichment" (p.301). Russia and Ukraine evince different policing styles of migrant workers, which can generally be defined as being extra-legal policing tactics in Russia and functional corruption in Ukraine.

\section{THE POLITICS OF MIGRATION}

With the collapse of the Soviet Union, the issue of internal economic migration become an international issue almost overnight. The regulatory regimes that followed, in both Russia and Ukraine, can be characterized as chaotic, lacking strategic vision, and often focused on the introduction of harsh laws. Light (2010) explains the development of the regulatory framework towards migrant labourers in the "closed city" of Moscow during Soviet times, and the reactive policing of mass phenomena such as unlawful residency in Moscow in post-Soviet times. Labour migrants in Russia are required to acquire residence registration and obtain a work permit within 30 days of arriving in Russia. Both procedures are highly complex, but supported by legal and illegal markets that facilitate different ways of dealing with the system (Urinboev, 2017; Light, 2010).

Ukrainian state policy regarding international labour migrants has also been "haphazard and fragmented in all its areas" (Fedirko, 2015, p.84). Although Ukrainian laws "On the Legal Status of Foreigners and Stateless Persons" and "On Immigration" define several relevant categories such as "foreigner", "stateless person", and "immigrant", there is no clear definition of the term "migrant worker" (Fedirko, 2015; Verkhovna Rada of Ukraine, 2001 and 2011). In both Russia and Ukraine, therefore, there is a legislative paradox with prohibitively strict regulations on the one hand, and an absence of clearly defined rights for migrant workers on the other. Zabyelina (2017) notes that: "the embeddedness of labour migration in the shadow economy promotes a business model that depends on a constant circulation of foreign labourers who are underpaid, insecure and ready to tolerate the unfair conditions" (p.95).

In contrast, the UK is a country where migrant workers can be roughly divided into two groups: those arriving from the European Union and those from other countries. The EU legal framework, combined with national enforcement mechanisms, has developed a stable legal background for migrant workers within the EU (subject to the uncertainties of the current Brexit negotiations).

The recent rise of populist political sentiment in Europe and beyond suggests that an antipathetic social attitude towards "others" dominates current debate (Melossi, 2000). The idea of the criminal migrant has influenced the political agenda in many countries, resulting in a perception that economic migrants tend to be criminals. Commenting on Melossi's dichotomy in categorizing immigrants, Cohen suggests that UK society's antipathy towards migrant workers could be equated with a "moral panic" (Cohen, 2011). This panic was bolstered by the media's coining the term, 
“criminal migrant" (see Endley, 2014; Hamilton, 2015; Drury, 2016). Behaviour perceived as "criminal" by immigrants ranges from violent crime to claiming benefits, wanting "something for nothing" (former Prime Minister David Cameron in an ITV interview, 2016). In the months leading up to the June 2016 UK Referendum on EU membership, the leader of UKIP identified migration as a principal issue of concern, "Leave's central argument that the UK cannot control the number of people coming into the country while remaining in the EU really hit home" (BBC, 2016b).

The views of UKIP resonate strongly with the views of officials in Russia, and specifically in Moscow. Abashin (2017) discusses how the 2013 Moscow mayoral election raised the issue of migration to the top of the agenda: "numerous phobias that had been previously morally or politically-censored gained in this debate a rather legitimate, politically-acceptable and even, in some senses, approved nature" (p.25). For example, Lassila (2017) analysed political discourse regarding migrant workers during elections and quotes one of the candidates during the campaign who said: "I'm not worried about the numbers related to migration, I am worried about every stolen handbag from women in my region" (p. 57). Commenting on recent migration policy, the mayor of Moscow, Mr Sobyanin, stated: "the most important achievement of reforms in foreign labour policies is the fact that there is a significant (30\%) decline in criminality amongst migrant workers". The mayor essentially represented migrant workers as a criminal class, repeating statistics suggesting that, in previous years, more than half of all crimes in Moscow were committed by migrants (Interfax, 2016). Such claims are highly controversial: they depend on biased policing and ignore the issue of the victimization of migrant workers and the immigrant population in general. In evidence, Obrazkova (2013) cites the raid on illegal migrant workers in Moscow that uncovered about 900 Vietnamese illegal workers. The authorities represented this case as a raid on illegal migrants, even though Human Rights activists have argued that the raid in fact uncovered slavery and exploitation (Ibid.). Light (2010) identifies an uneasy symbiosis that exists between government and the police: "some kinds of police abuse are tolerated by the city (even though not desired) because they are necessarily attendant on other kinds of abuse (which are desired)" (p.303).

In Ukraine, social antipathy towards migrants and xenophobia is also widespread. Fedirko (2015) quotes research conducted by the Kiev International Institute of Sociology that suggests " $19.4 \%$ of respondents would prefer not to give permission to immigrants from poor countries to live and work in Ukraine" (p.84). This is surprising when we consider that over the past 20 years up to 15 per cent of people of working age left Ukraine in search of work abroad (Radchuk, 2016), and in fact the official number of migrant workers in Ukraine remains small.

By contrast, regarding the UK's 'sympathetic' social perspective, a moral panic has also emerged that emphasizes that immigrants are often the victims of crimes (Dugan, 2015; Cowan, 2016; Adesina \& Fayaz, 2016). The UK's Modern Day Slavery Act 2015 was considered "landmark legislation" (May, 2015) that aimed at strengthening protections for survivors (Haughey, 2016). However, despite this legislative progress, the practical investigation of exploitation and slavery remains very difficult.

In this article we are interested in the way migrant workers view the police in host and home countries, and the interaction between home and host experiences of policing. We are seeking to understand similarities and differences in policing experiences across different locations.

\section{METHODOLOGY}

The data for our study were collected in 2011-2012 and include 138 semi-structured interviews with migrant workers (Table 1). The ethics review was conducted according to the Anglia Ruskin University ethics procedure. We used a community-based respondent driven sample of migrant workers in three field areas: England, Russia and Ukraine. It was important to us to contrast policing in the migrants' country of origin from policing in their country of destination or host country. 
TABLE 1

DEMOGRAPHIC CHARACTERISTICS OF RESPONDENTS

\begin{tabular}{|c|c|c|c|c|c|c|}
\hline \multirow[t]{2}{*}{$\begin{array}{l}\text { Host country } \\
\text { (country of } \\
\text { destination) }\end{array}$} & \multicolumn{6}{|c|}{ Age (years) } \\
\hline & Mean & Min & Max & Median & $\mathrm{SD}^{*}$ & Variance \\
\hline \multirow[t]{3}{*}{$\begin{array}{l}\text { Russia } \\
\text { England } \\
\text { Ukraine }\end{array}$} & $\begin{array}{l}30,88 \\
31,34 \\
41,27\end{array}$ & $\begin{array}{l}18,00 \\
19,00 \\
30,00\end{array}$ & $\begin{array}{l}65,00 \\
55,00 \\
54,00\end{array}$ & $\begin{array}{l}27,50 \\
29,00 \\
42,00\end{array}$ & $\begin{array}{r}10,46 \\
9,42 \\
7,11\end{array}$ & $\begin{array}{r}109,47 \\
88,66 \\
50,62\end{array}$ \\
\hline & \multicolumn{2}{|c|}{ Gender ( $\%$ and $N$ of cases) } & & & & \\
\hline & Male & Female & & & & \\
\hline \multirow[t]{3}{*}{$\begin{array}{l}\text { Russia } \\
\text { England } \\
\text { Ukraine }\end{array}$} & $\begin{array}{r}100 \%(52) \\
58,1 \%(36) \\
90,9 \%(20)\end{array}$ & $\begin{array}{c}0 \% \\
41,9 \%(26) \\
9,1 \%(2)\end{array}$ & & & & \\
\hline & \multicolumn{4}{|c|}{ Marital status (\%) } & & \\
\hline & Single & Married & Divorced & Widowed & & \\
\hline \multirow[t]{3}{*}{$\begin{array}{l}\text { Russia } \\
\text { England } \\
\text { Ukraine }\end{array}$} & $\begin{array}{r}46,2 \% \\
43,3 \% \\
9,1 \%\end{array}$ & $\begin{array}{l}42,3 \% \\
46,7 \% \\
81,8 \%\end{array}$ & $\begin{array}{r}11,5 \% \\
10,0 \% \\
0,0 \%\end{array}$ & $\begin{array}{l}0,0 \% \\
0,0 \% \\
9,1 \%\end{array}$ & & \\
\hline & \multicolumn{4}{|c|}{ Number of children (\%) } & & \\
\hline & 1 & 2 & 3 & 4 & & \\
\hline \multirow[t]{3}{*}{$\begin{array}{l}\text { Russia } \\
\text { England } \\
\text { Ukraine }\end{array}$} & $\begin{array}{l}23,1 \% \\
29,4 \% \\
44,4 \%\end{array}$ & $\begin{array}{l}53,8 \% \\
52,9 \% \\
22,2 \%\end{array}$ & $\begin{array}{l}23,1 \% \\
11,8 \% \\
22,2 \%\end{array}$ & $\begin{array}{r}0,0 \% \\
5,9 \% \\
11,1 \%\end{array}$ & & \\
\hline & \multicolumn{4}{|c|}{ Education (\%) } & & \\
\hline & School & $\begin{array}{l}\text { Vocational } \\
\text { college }\end{array}$ & University & $\begin{array}{l}\text { Degree not } \\
\text { completed }\end{array}$ & & \\
\hline $\begin{array}{l}\text { Russia } \\
\text { England } \\
\text { Ukraine }\end{array}$ & $\begin{array}{r}53,8 \% \\
30,0 \% \\
0,0 \%\end{array}$ & $\begin{array}{l}34,6 \% \\
13,3 \% \\
27,3 \%\end{array}$ & $\begin{array}{r}7,7 \% \\
43,3 \% \\
63,6 \%\end{array}$ & $\begin{array}{r}3,8 \% \\
13,3 \% \\
9,1 \%\end{array}$ & & \\
\hline
\end{tabular}

${ }^{*} \mathrm{SD}=$ Standard Deviation

Based on the 2010 Corruption Perception Indexes of Transparency International (TI, 2010), we have assigned our respondents to the following groups: those from countries that experience a high level of corruption (Ukraine and Nigeria) moving to host countries with a high level of corruption (Russia and Ukraine); and those from countries that experience a high level of corruption (Lithuania) moving to host a country with a significantly lower level of corruption (the UK). 
Respondent-driven sampling (RDS), or snowball sampling, was used in all three field areas. Migrant workers were approached through their national communities by introduction by a community representative. This significantly increased the level of participant trust during interviews, and thus improved data validity. In Moscow, our first contact was a person with a university degree in the natural sciences, who had resigned from his low-paid job in a research institute in Ukraine to begin a self-employed career as a migrant worker in Moscow. During the summer of 2011 this person volunteered to keep a diary of his encounters with the police, his employers, and the public in Moscow. This diary reveals useful and often hidden insights into the subject's routine encounters with corrupt police officers, and his rationalization of these encounters. We quote extracts from this diary with the permission of its author. In Moscow all interviews were conducted in Russian and took place outside the participant's hostels. In total, 52 respondents were interviewed; 47 Ukrainians, 3 Uzbekistanis and 2 Moldovans. Respondents from Uzbekistan and Moldova did not answer any of the open-ended questions, and our attempts to increase their numbers in the sample were not successful. So, the Moscow sample is mostly representative of the experience of Ukrainian workers.

The Nigerian community was approached through a community leader, a graduate of an Ukrainian university. This community leader had advised us that there were a number of Nigerian migrant workers selling goods at the Barabashova open market, one of the biggest open markets in Eastern Ukraine, situated in Kharkiv. There, we were able to approach a dispersed group of sellers, working at different locations and selling varied goods. Interviews were conducted in English and took place either in the open market or in its café. During our interviews all Nigerian respondents identified themselves as migrant workers. In total 22 Nigerians were interviewed in the city of Kharkiv.

Lithuanian migrant workers were approached through members of the Lithuanian cultural community during a community organized cultural event in Cambridge. Interviews took place in a variety of locations in Cambridge, Huntingdon and Kings Lynn. In all, 64 Lithuanians were interviewed in England, in Norfolk and Cambridgeshire.

With regard to our methodology, there are three important clarifications. Firstly, one disadvantage of our sample is a significant underrepresentation of female migrant workers. Due to time constraints, it was necessary to recruit respondents from compact samples. For example, in Moscow, most of our respondents were renting rooms in an old students" hall of residence ("obshezhitie" in Russian). All these residents were males employed at different building sites in Moscow. The International Organisation for Migration (IOM, 2017) estimates that one third of expatriate Ukrainian migrant male workers are employed in construction. Identifying female migrant workers would require a different approach due to the different nature of their employment, such as child-minding or housekeeping.

The second point to be made concerns the issue of the migration flow and the political situation that has a potential to affect the sample. In 2011, Ukrainian migrant workers considered Moscow a popular destination. However, since the beginning of the conflict in the East of Ukraine in 2014, the Ukrainian pattern of work migration has changed. According to IOM (2017), in Ukraine "the preference of the Russian Federation as a country of destination continues to decrease (from $18 \%$ of respondents who expressed the desire to work abroad in 2011, to $12 \%$ in 2015, and to $9 \%$ in 2017)".

The third issue to take into consideration is the issue of self-identification, specifically identifying oneself as a migrant worker. We relied on our respondents to identify their status. While an official definition of a migrant worker exists in the UK and Russia, in Ukraine, incoming foreign work migration is a relatively new issue. According to the State Border Guard Service control, 90 per cent of foreigners arrive in Ukraine as private tourists (Fedirko, 2015). The official data on incoming labour migration for the period of 2006-2013 revealed that they represented less than one per cent of the total number of foreigners arriving. In 2008 there were 12,200 foreign migrant workers registered (Fedirko, 2015). We note, however, that official data on migrant labour can miss a significant proportion of foreigners arriving in Ukraine to work but remaining on student visas. In 2016, the number of foreign students in Ukraine reached 63,906, including about 3,500 from Nigeria (Ministry of Education and Science, 2016). 
Fourthly, there is reluctance to talk about the experience of policing. This was evident when approaching migrant workers from Uzbekistan and Moldova. The distrust of authorities, and any members of the public who can potentially represent authority, was particularly visible in this sample. We consider that the best way to explore the experience of a particular group was to be introduced by a member of this group, although that did not happen in the case of the two groups named above.

The questionnaire comprised of 99 quantitative and qualitative (open-ended) indicators. The measures for this study were selected by the authors based on their previous experience of using these measures in their Ukrainian and UK research, where such had shown good diagnostic properties with sensitive criminological indicators (Serduyk \& Markovska 2012a; Serduyk \& Markovska, 2012b). The interviews covered nine themes concerning the participants' relationship with the police in their home and host nations, their experience as victims and as perpetrators of crime, their experiences of xenophobia and racism (Personal experience; Bogardus scale; Ethnohomogenic Orientation Scale), and their experiences of corruption. Data were analysed using the software package SPSS v17. Cross-tabulation themes were extracted from the open-ended questions in order to contextualize, code and categorize answers for each group of the respondents.

The quantitative indicators as described below (Table 3) were measured with the help of a 5 positional scale (Yes, Rather Yes, Neutral, Rather No, No). For convenience, the data were re-coded to assign numerical value to the answers: Yes $=+1$; Rather yes $=+0.5$; Neutral $=0$; Rather No $=-0.5$; No $=-1$. Indices fluctuate from -1 to +1 . This measure represents the median average of participant responses to a given issue. -1 indicates a wholly negative, disagreeing response to a question or statement. +1 indicates a wholly positive, agreeing response to a question or statement. For example, regarding the question; "Is there a denial of a crime problem among migrant workers", a -1 score would mean that participants believe there to be a complete denial of a crime problem existing among migrant workers. Whereas a +1 score would mean the complete agreement of participants that a such crime problem existed (see the study variables table at the end of this article).

\section{RESULTS}

Each group of migrant workers has a unique immigration situation that has developed due to the socio-economic and political conditions in their country of destination (Table 2).

Data collected during the interviews suggest the following:

1) On average, Ukrainian migrant workers in Russia stayed in the country for 17 months. The goal of this short stay was to earn enough money to accumulate a sizable sum, then return to Ukraine.

2) The average stay of the Lithuanian workers in England was 59 months.

3) An average length of stay for Nigerian migrant workers in Ukraine was 145 months. During the interviews it transpired that there were at least two specific groups of migrant workers from Nigeria: those who came to work or study, and those who used Ukraine as a transit stop on the way to other Western European destinations.

Overall, respondents in our study can be divided into two groups of temporary migrant workers: those arriving for a short stay, "to earn and leave" (in Russia), and migrants who intend to stay in the country for longer periods (England and Ukraine).

\section{CRIMINALITY AND MIGRATION}

Migrants' personal understanding of criminality within their community is presented in Figure 1 below. It shows that in Russia, migrants tend to deny the problem of criminality within their community while in England, respondents accepted its existence. 
TABLE 2

DESCRIPTIVE STATISTICS FOR THE VARIABLE "LENGTH OF STAY IN HOST COUNTRY (COUNTRY OF DESTINATION)"*

\begin{tabular}{|l|rrrrrr|}
\hline Host country (country of destination) & Mean & Min & Max & Median & SD & Variance \\
\hline Russia & 16,77 & 0,50 & 70,00 & 7,25 & 18,81 & 353,99 \\
England & 59,00 & 2,00 & 180,00 & 60,00 & 41,02 & 1682,84 \\
Ukraine & 145,45 & 60,00 & 216,00 & 172,00 & 52,89 & 2797,67 \\
\hline
\end{tabular}

*length of stay in host country (country of destination) measured in months; SD = Standard deviation

FIGURE 1

MIGRANT WORKER'S VIEW ON CRIMINALITY OF THE FELLOW MIGRANTS

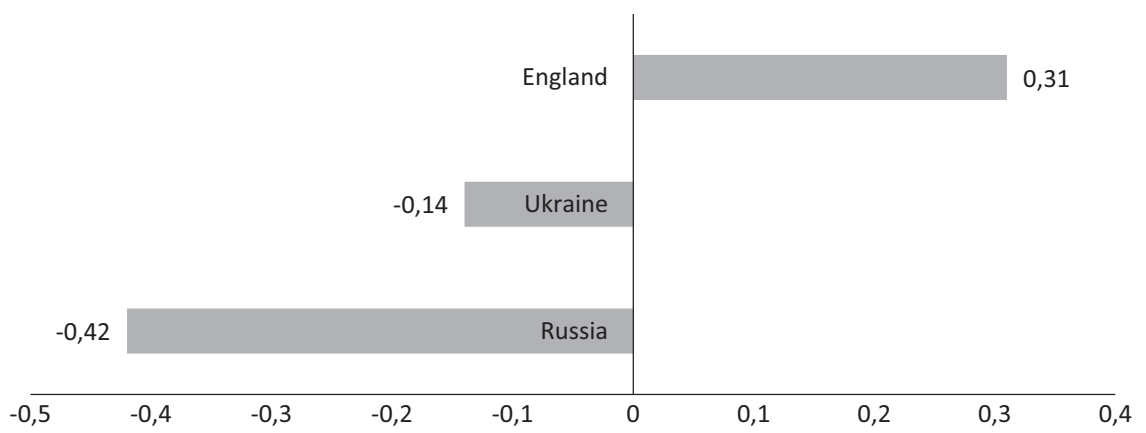

Notes: -1 means "denial", +1 means "acceptance" of perception that criminality can be linked to the community of migrant workers.

Contrary to the official view in Moscow that "migrants used to commit half of all the crime in the city" (Interfax, 2016), work migrants in our sample are very critical of the media representation of migrant workers as criminals.

\section{Victimization and Criminalization at Work}

Respondents were asked to comment on the organization of their day-to day work. We wanted to know if the nature of their employment encouraged its perception as being linked with criminality and victimization. Indices of these estimates are shown in Figure 2 below.

The distribution of indices is represented between -1 and +1 regarding the "victimization of work-related activities" (the belief that the organization of work related activities leads to criminal activity against migrant workers) and "criminogenic work activities of migrant workers" (the belief that the organization of work-related activities leads to migrant workers engagement in criminal activity in their country of destination). In Figure 2, -1 means total denial, and +1 means total agreement. It shows the distribution of the perception of the victimization of work related activity and criminogenic work related activity with regard to migrant workers in England, Ukraine \& Russia. 
TABLE 3

STUDY VARIABLES (QUANTITATIVE)

\begin{tabular}{|c|c|c|c|c|c|}
\hline Variable name & Question & Labels & $\begin{array}{c}\text { Recoding } \\
\text { labels to Index }\end{array}$ & $\begin{array}{l}\text { Index } \\
\text { Mean }\end{array}$ & SD \\
\hline $\begin{array}{l}\text { Denial of } \\
\text { crime }\end{array}$ & $\begin{array}{l}\text { Does the problem } \\
\text { of criminality } \\
\text { exist within your } \\
\text { community of } \\
\text { migrant work- } \\
\text { ers? }\end{array}$ & $\begin{array}{l}\text { Yes; Rather } \\
\text { yes; Not } \\
\text { sure; } \\
\text { Rather no; } \\
\text { No }\end{array}$ & $1 / 0,5 / 0 /-0,5 /-1$ & $-0,04$ & 0,61 \\
\hline $\begin{array}{l}\text { Victimisation } \\
\text { by work } \\
\text { related } \\
\text { activity }\end{array}$ & $\begin{array}{l}\text { Do you think the } \\
\text { nature of your } \\
\text { employment in } \\
\text { this country } \\
\text { encourages } \\
\text { criminality } \\
\text { against you? }\end{array}$ & $\begin{array}{l}\text { Yes; Rather } \\
\text { yes; Not } \\
\text { sure; } \\
\text { Rather no; } \\
\text { No }\end{array}$ & $1 / 0,5 / 0 /-0,5 /-1$ & $-0,20$ & 0,74 \\
\hline $\begin{array}{l}\text { Criminogenic } \\
\text { work- related } \\
\text { activity }\end{array}$ & $\begin{array}{l}\text { Do you think that } \\
\text { the nature of } \\
\text { your employ- } \\
\text { ment encour- } \\
\text { ages your own } \\
\text { criminal con- } \\
\text { duct? }\end{array}$ & $\begin{array}{l}\text { Yes; Rather } \\
\text { yes; Not } \\
\text { sure; } \\
\text { Rather no; } \\
\text { No }\end{array}$ & $1 / 0,5 / 0 /-0,5 /-1$ & $-0,23$ & 0,77 \\
\hline $\begin{array}{l}\text { Police } \\
\text { engagement } \\
\text { in criminal } \\
\text { conduct }^{*}\end{array}$ & $\begin{array}{l}\text { Do you think } \\
\text { police in your } \\
\text { home country } \\
\text { participate in } \\
\text { criminal con- } \\
\text { duct? } \\
\text { (Do you think } \\
\text { police in this } \\
\text { country engage } \\
\text { in criminal con- } \\
\text { duct?) }\end{array}$ & $\begin{array}{l}\text { Yes; Rather } \\
\text { yes; Not } \\
\text { sure; } \\
\text { Rather no; } \\
\text { No }\end{array}$ & $1 / 0,5 / 0 /-0,5 /-1$ & $0,64(0,17)$ & $0,62(0,79)$ \\
\hline $\begin{array}{l}\text { Trust to } \\
\text { police* }\end{array}$ & $\begin{array}{l}\text { Do you trust } \\
\text { police at home? } \\
\text { (Do you trust } \\
\text { police in this } \\
\text { country?) }\end{array}$ & $\begin{array}{l}\text { Yes; Rather } \\
\text { yes; Not } \\
\text { sure; } \\
\text { Rather no; } \\
\text { No }\end{array}$ & $1 / 0,5 / 0 /-0,5 /-1$ & $-0,49(0,06)$ & $0,75(0,90)$ \\
\hline $\begin{array}{l}\text { Attitude to } \\
\text { police in } \\
\text { general }^{*}\end{array}$ & $\begin{array}{l}\text { What do you think } \\
\text { about police offi- } \\
\text { cers in your } \\
\text { home country? } \\
\text { (What do you } \\
\text { think about } \\
\text { police officers in } \\
\text { this country?) }\end{array}$ & $\begin{array}{l}\text { Positive; } \\
\text { Rather } \\
\text { positive; } \\
\text { Neutral; } \\
\text { Rather } \\
\text { negative; } \\
\text { Negative }\end{array}$ & $1 / 0,5 / 0 /-0,5 /-1$ & $-0,40(-0,10)$ & $0,53(0,76)$ \\
\hline $\begin{array}{l}\text { Personal } \\
\text { reaction to } \\
\text { meeting a } \\
\text { police } \\
\text { officer }^{\star}\end{array}$ & $\begin{array}{l}\text { Have you ever } \\
\text { had an encoun- } \\
\text { ter with police in } \\
\text { your home coun- } \\
\text { try? } \\
\text { (Have you ever } \\
\text { had an encoun- } \\
\text { ter with police in } \\
\text { this country?) }\end{array}$ & $\begin{array}{l}\text { Positive; } \\
\text { Rather } \\
\text { positive; } \\
\text { Neutral; } \\
\text { Rather } \\
\text { negative; } \\
\text { Negative }\end{array}$ & $1 / 0,5 / 0 /-0,5 /-1$ & $-0,38(-0,28)$ & $0,45(0,76)$ \\
\hline
\end{tabular}

*Variable measured according host country (country of destination) and home country (country of origin), the formulation of the question changes depending on the variable; $S D=$ Standard deviation 
FIGURE 2

CRIMINOGENIC ENVIRONMENT AT WORK VS VICTIMIZATION AT WORK

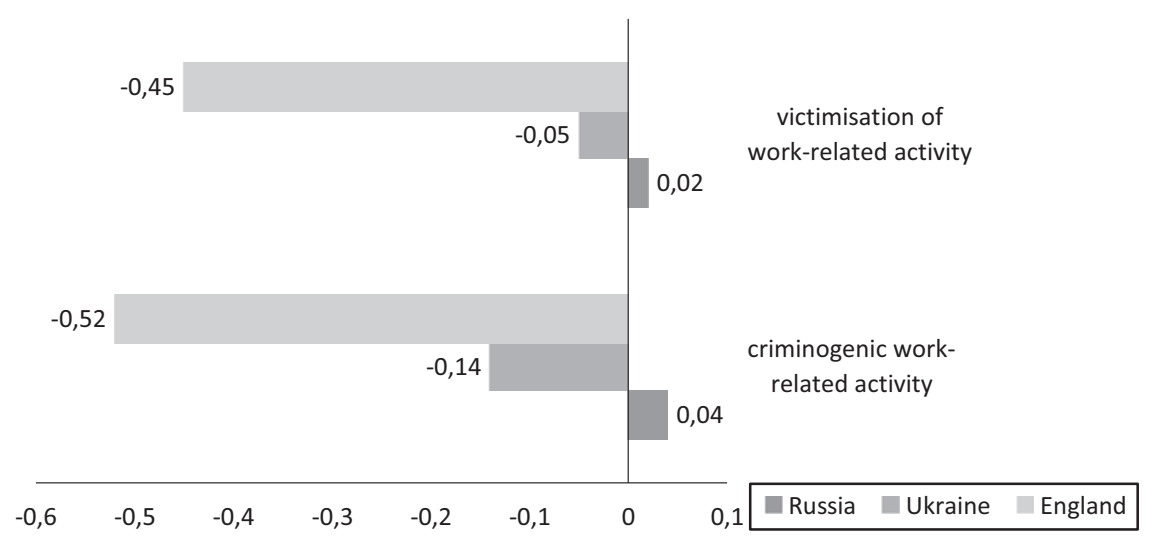

Notes: -1 means "totally disagree", +1 means "totally agree" with statements that "employment rights of migrant workers are not protected by law and this situation encourages informality and criminal conduct against migrant workers" and "the nature of employment encourages illegal conduct by migrant workers in the country of destination".

An analysis of the types of crimes migrant workers are perceived as being involved in, suggests the following. In Russia migrant workers mostly work illegally without paying taxes or registering for work and residency officially. The main explanation offered for this is difficulties with bureaucracy; as one respondent put it "I am a forced illegal". In the UK (with regard to the Lithuanian migrant workers) the main problems reported were tax evasion and hooliganism. In Ukraine, Nigerian migrant workers reported that tax evasion and drug trafficking were the major concerns, although many noted that the latter had declined by 2010 .

Regarding crimes committed against migrant workers, the data suggest a different situation. In Russia, migrant workers reported victimization and extortion by police officers and misleading verbal work contracts as being major concerns. It was often the case that these workers would be promised a certain level of pay but then, after the work was done, they would not be paid the agreed amount. Such unjust, fraudulent, practices are perceived as an institutional norm by migrant workers in Russia. This is supported by the following diary extract:

"The main aim of any employer is to pay less and to earn more. Even in cases of legal employment you can be deprived of your usual bonus for 'long-hours payment' with little explanation. In my current legal employment, $30 \%$ of our salary is considered as a bonus payment. This bonus payment comes and goes without consultation. When considering illegal employment, it is essential to receive good recommendation, meaning that the employer actually pays. The standard practice of the illegal employment is to offer minimum pay for food during the duration of the project and refuse to pay at the end, suggesting some sort of troubles within the organisation...I have never heard about the situation when legal or illegal employed migrant worker officially complained about non-payment".

This failure of employers to comply with either written or oral contracts is reported by both legally and illegally employed migrant workers. In both Russia and Ukraine, the informal sector of the economy is significant (Polese, 2014). Informal employment is employment that is not registered officially and therefore hidden from the state (Ibid.). Theoretically, employment within the formal sector of the economy should be protected; in practice, however, migrant workers do not 
enjoy significant protection. On a personal level, it is the trustworthiness and honesty of their employers that provide any security to the migrant worker.

In England, Lithuanian migrant workers tend to be better protected by law. In 2011 Lithuanian migrant workers identified hooliganism and theft as the main crimes committed against them within their community. One Lithuanian respondent reported a rising level of informal settling-in practices within the migrant communities. Such practices included an established migrant worker helping newcomers to rent rooms and arrange a cheap supply of alcohol and cigarettes from Lithuania. These practices can potentially provide an opportunity for exploitation when applied to vulnerable migrant workers.

The above practice of the abuse of vulnerable members of the same migrant community has also been reported in Russia. Urinboyev (2017) describes a group of migrant workers from the same village in Uzbekistan. They were forced to live in terrible conditions on a building site, and were left without pay for over three months by those who were meant to "look after them", men from the same village who had arrived in Moscow earlier. Such exploitation is considered to be an everyday reality for thousands of migrant workers in Moscow. Specific terminology to describe such exploitation and abuse has not yet, however, reached the level of popular political discourse in either Russia or Ukraine. Migrant workers in our Moscow and Kharkiv samples largely agreed that the informality of their working arrangements coupled with police corruption has a significant impact on their safety. The following extract from a diary cited earlier is a poignant reminder of this:

"Two years ago I worked at a building site during winter months. Many workers were illegal, and stayed on-site overnight, sleeping in wooden sheds. In the evening, the site would usually be visited by police to extort money. In order to avoid this, labourers would lock themselves in from the outside. One cold night the heater caught fire and burned 3 workers alive".

The Ukrainian migrant workers emphasized that such criminal activity on the part of the police was directly encouraged by to their illegal status and the difficulty of obtaining legal work. However, even when their employment and status are legal, migrant workers are forced to pay bribes to the police in Moscow. These experiences of victimization by migrant workers stand in striking contrast with official statements. In 2016, the mayor of Moscow asked police officers and volunteers from various public crime-prevention teams to continue activities aimed at identifying and suppressing illegal migration into the city (Interfax, 2016). However, human rights activists in Moscow argue that such victimization is the result of officials' heavy-handed response to the vexed issue of labour migration in the public perception and a lack of initiative to tackle labour exploitation and slavery (Obrazkova, 2013).

Most of the Nigerian migrant workers interviewed in Ukraine worked at the biggest open market in the city of Kharkiv, selling clothes and accessories. Most of them worked on their own behalf or were employed by fellow members of their community. Most identified extortion, theft, and hooliganism (mainly racially motivated) as their main concerns. One Nigerian migrant worker reported: "drunken people who want to fight are my biggest problems"... "they call us monkeys". From our conversation it transpired that many Nigerians are "zoning" the city, and understand the dangers to them that different zones present. For example, the city centre with its many universities is considered to be a relatively safe zone. Their place of work (the market) and their "sleeping" districts represent areas of danger. In these zones, even walking the streets can pose problems. For example, police officers may stop and search an individual, and extort money from them. Also, racially motivated attacks from locals at any time of day remain a possibility. In the evening, the threat of physical violence is present from drunk, aggressive and homophobic local men. 
FIGURE 3

PERCEPTION OF POLICE IN DESTINATION COUNTRY

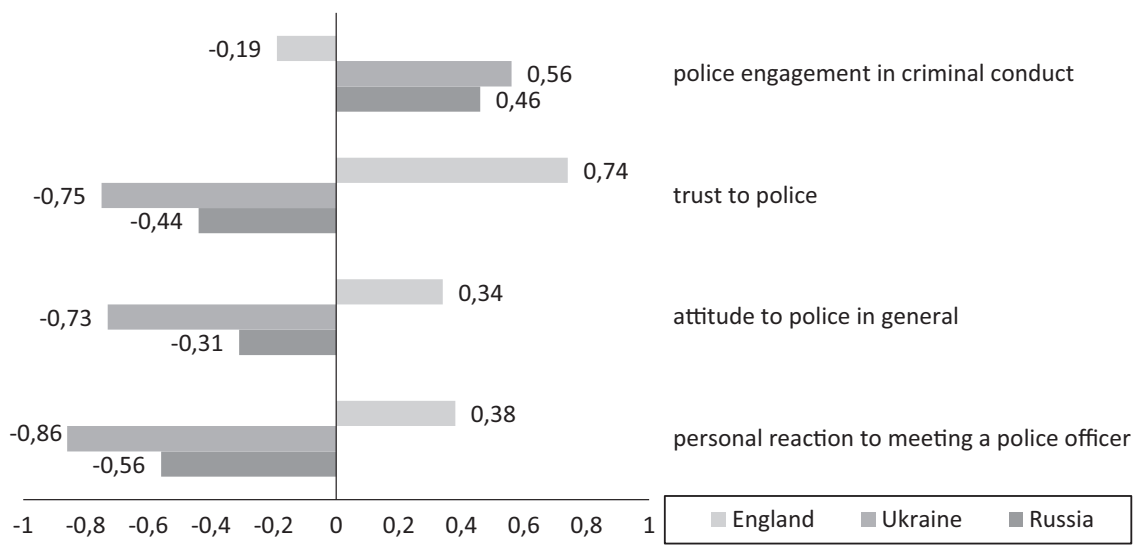

Notes: Police engagement in criminal conduct: -1 means not engaged, +1 means "engaged"; Trust to police: -1 means "mistrust", +1 means "maximal trust"; attitude to police in general: -1 means "negative", +1 means "positive"; personal reaction to meeting a police officer: -1 means "negative", +1 means "positive".

\section{RELATIONSHIP WITH POLICE IN THE HOST COUNTRY}

We are interested in migrant workers' experience of policing at street level. Figure 3 shows the distribution of indices of their subjective estimation of policing in the host country.

The interaction of migrant workers with the police differs significantly between the three countries investigated. In Russia and Ukraine, respondents tend to believe that illegal police activity is widespread. In contrast, participants from England reported that illegal activities committed by police were not common. For example, one participant claimed: "I haven't had any illusion regarding police in the UK, there was nothing to change. They all talk a lot and do very little, they show that they do a lot, but in reality not. Here is an example. I was stopped by police in Newmarket, they checked my documents, and after 15 minutes of checking they asked me to move my car and put it in front of their car, and I did it. They issued a fine of 70 pounds because I didn't signal during this manoeuvre". Regardless, of such experiences migrant workers living in England generally trust the English police. This is in contrast to the perception of police officers by migrant workers in Russia and Ukraine. There respondents report a significant absence of trust and an overall negative attitude.

All respondents were asked to identify typical features of the police in their host country. In England police were said to be "friendly, polite, fit, fast, competent, knowledgeable, professional, honest, positive, trustworthy, do not lie, and work to abide by the law". "Respect and honesty" were mentioned by all of these respondents who largely agreed that English police were "friendly". One Lithuanian participant reported: "They look like they are honest people...here policemen can be your friend, they do not want to create distance and be different from the others, I do not feel their presence here, they are good men". One negative characteristic reported regarding English police, however, related to the issue of bureaucracy. Respondents claimed that there was excessive bureaucracy surrounding the practicality of policing, but that in general British police officers were "strict but fair". Only one respondent gave police in Britain a very negative description, saying that "they hate foreigners, talk a lot and do very little". The respondents from England also largely agreed that British police are approachable and professional, stating that: "they are calm, not armed, look friendly and are not afraid to smile". This general experience provides a counterpoint to the mass 
of literature concerning poor relationships between police and migrant communities within the UK (Bowling et al., 2003).

The above is in marked contrast to how Russian police officers were perceived. Migrant workers in Moscow made the following remarks when referring to Russian police: "rough", "greedy", "ignorant of the law", "corrupt", "they show no respect to human beings", and "are more concerned about their personal benefits", "cowards, greedy, and without principles", "often abuse their workrelated duties, but all people are different".

In 2011 Ukrainian migrant workers reported similarities between Russian and Ukrainian policing. Typical respondent remarks included: "[Russian] police officers are very similar to Ukrainian, only more aggressive and more daft"; "Corrupt and bribe-seeking behaviour', 'absence of the respect to ordinary citizens, authoritarian style", "police is my every-day problem, it does not matter what I do or do not do, I will still be expected to pay a bribe", "good police officers are the educated ones" and "if they want they can work well".

The previously referred to diary includes the thoughts of its author regarding his experience of using the underground system in Moscow: "The eyes of officers on duty at each underground station are constantly 'hunting' for victims. If they see a non-Slavic face, person with many bags or just a person who is unsure about making an eye contact with them, they will stop them and start the document check.... Even local citizens go out to buy bread with the passport in their pocket". Interestingly, however, it seems that not all encounters with police end up with the extortion payment actually being paid. For example, the following encounter was recorded by the diarist: "... As we are placing the advert on a multi-storied building, we learn that one old lady called police to report on our activity. Police arrived and on their request we show all the papers regarding our work requirements and permit for the poster we are working on. During our conversation, police noticed that my colleague speaks with a heavy Ukrainian accent. Police, "where are your passports, you must be khokhlu [people from Ukraine, the term often used to humiliate]? I say, "why do you think so?" They reply, "Who else would do this job?! Go and sit in our car." Our driver later told us that the police told him not to worry, "we will take a little, and let them go." They took us in their car to the police station and stopped in front of the station. One officer, "So, what are we going to do?" My colleague replies, "We are working legally, you can call our company, here is the number." They say, "Maybe you need to think more". My colleague, "When I do something wrong, I know what to do, but we have all papers in order, so don't expect anything". After 15 minutes of similar exchanges police say, "Go away!"

This extract shows that resisting extortion demands from police officers is challenging, requiring resilience and persistence. In this case the migrant workers were working legally, experienced, well educated, and aged over 55. Yet still they found themselves enduring a short intimidating illegal detention in a police car. Moscow police jokily refer to this practice as "thinking time". It is also important to note that police use migrants accents to identify their country of origin, in this case, the Ukrainian national was so identified and consequently referred to in a derogatory way. This can be described as an example of nationalist or "imperialist" policing. While it is almost impossible to visually distinguish a Ukrainian national from a Russian, the Ukrainian accent is easily discernible to indigenous Russians. Such an example accords with the discussion of harassment of migrant workers in Moscow by Light (2010) that targets a similar harassment aimed at ethnic Russians so they are no longer "immune from document checks" (p. 299).

Nigerian migrants largely believe that the Ukrainian police "always take the side of the white citizens", and "always want us to be quiet when dealing with them on the streets". The Nigerian migrant workers perceive police in Ukraine as being "worse than in Nigeria". It is possible that Nigerian migrant workers view Nigerian police as less corrupt because at home in Nigeria they have more chance to have their rights respected and to be policed equally. Ukraine is a homogeneous country, with almost 88 per cent of population being of Ukrainian and Russian extraction (Index, 2016). The Nigerian community is therefore a highly visible minority and an easy target for corrupt Ukrainian police officers; in this way racism might take on a mercenary aspect, in that 


\section{FIGURE 4}

PERCEPTION OF POLICE IN HOME COUNTRY (COUNTRY OF ORIGIN)

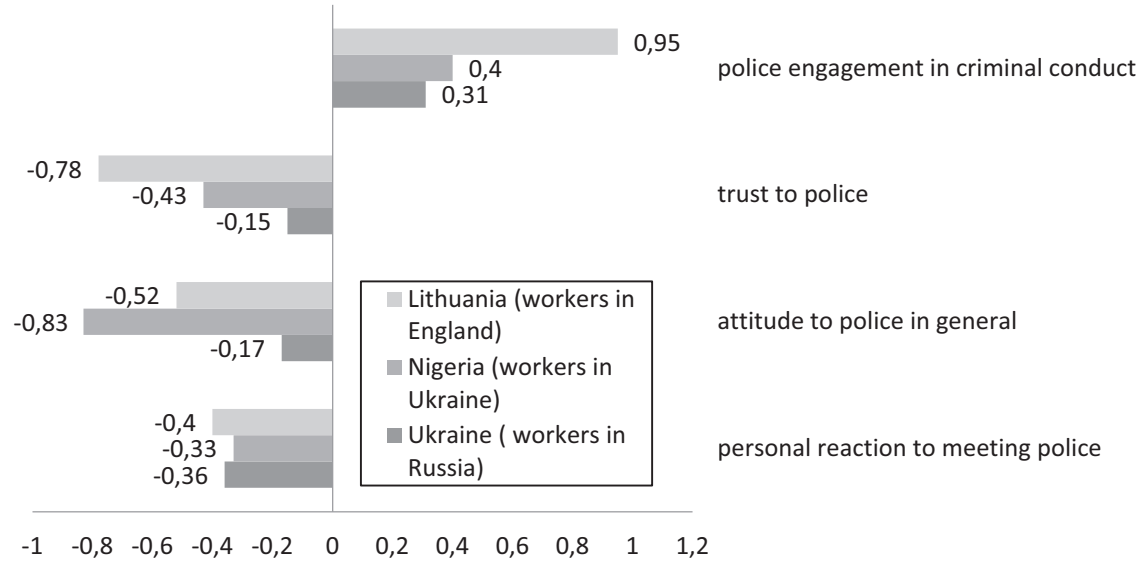

Notes: Police engagement in criminal conduct: -1 means "not engaged", +1 means "engaged"; Trust to police: -1 means "mistrust", +1 means "maximum trust"; attitude to police in general: -1 means "negative", +1 means "positive"; personal reaction to meeting a police officer: -1 means "negative", +1 means "positive".

police can readily identify a Nigerian and, once identified, the Nigerian becomes an easy target for extortion. The Nigerian community has consequently adapted to overtly racist policing by identifying areas of the city that are least likely to be problematic, those free from corrupt police and racist locals, and modify their daily routine accordingly. One strategy for not attracting attention was reported by a Nigerian respondent: "driving a car in Kharkiv is out of question for me, a black man behind the wheel attracts road police attention all the time".

\section{MIGRANT WORKERS ABOUT POLICE IN THEIR COUNTRY OF ORIGIN}

The Figure 4 shows how migrant workers perceive the police of their country of origin (home country).

Respondents are united in giving negative accounts (between 0 and -1) to policing in their country of origin. Nigerian and Ukrainian migrant workers say that in their home countries unlawful activities of police officers are common. Nigerian respondents largely agreed that there were two stereotypes of police officers in their home country: those who were well-educated, and then those that were essentially uneducated, holding that the "well-educated stay in their offices and uneducated get sent to the streets". Lithuanian respondents complain of corruption within the police force of Lithuania and gave the most negative response regarding their encounters with police officers there. Responding to the question: "What do you think are the typical features of the police officer at home?", a Lithuanian respondent stated: "corrupt, ignorant, rough, impertinent, not professional, aggressive, cruel, boor, arrogant, dishonest, mediocrity, do nothing, not trustworthy, do not think about citizens, have problems communicating, IQ lower than average, love to drink, believe in their superiority, often cross the line of their duties, use torture to get evidence... [...] ...love money, if you have money they will speak to you, they had too much... [... . ...they are walking Gods, it's best not to cross their path, and everyone knows this". Other Lithuanians remarked, on the subject of Lithuanian police as "vile, impudent, fat because of bribes, arrogant, think they must have been bullied at school'; "you are afraid that they will make up a case against you", "they work not to help ordinary citizens", and 
"they create lots more trouble, than establish order". It is the Lithuanian group of migrant workers who report the most visible difference between policing in their country of origin and destination.

\section{DISCUSSION AND CONCLUDING REMARKS}

The experience of policing by migrant workers is highly complex. We consider three factors that determine the perception of policing strategy in the host country by migrant workers: experience of corruption at home prior to the move to the host country; politicization of police and antipathy of the media and public in the host country; exploitative practices within communities of migrants in the host countries.

Most migrant workers interviewed had experienced corrupt policing practices, and anticipated a certain level of police corruption in their host countries. In the host country where migrant workers did not experience corruption, they appreciated the new style of policing, often described as a "friendly" and "kind". The anticipation of corrupt policing is particularly relevant for Ukrainian migrant workers in Russia and Nigerian migrant workers in Ukraine. Ukrainian migrant workers arrived in Moscow with an expectation of corrupt interactions between citizens and police based on their home experience. This group of migrants did not expect to find any significant difference between policing in their home and host countries. In other words, they knew how to play the system and were already familiar with the corrupt policing practices that they encountered in their host countries. In this regard, their experience of the Ukrainian police played a critical role in their adaptation to the policing they experienced in Moscow. They realized that in Moscow they would be more visible due to the nature of their work and/or because of their Ukrainian accent. In both Russia and Ukraine, police corruption presents a daily threat to migrant workers. The Nigerian community in Ukraine reported that, in addition to corruption and racism on the part of the police, they faced regular random racist attacks from the local population.

Continual social antipathy towards migrant workers is often sustained through biased, politically influenced media reports and corrupt policing practices. Such antipathy thrives on reports of crimes that are allegedly committed by migrant workers. Given such considerations, reporting on the nature of the victimization experienced by migrant workers is a challenging task. This is especially the case in countries such as Russia and Ukraine where police corruption creates an atmosphere of insecurity for many vulnerable groups. The experience of policing by migrant workers could be improved by better enforcement of their legal rights and police acknowledgement of the different patterns of victimization experienced by migrant workers with subsequent action within the force to prevent it.

\section{ACKNOWLEDGEMENTS}

The first author would like to thank the British Academy for providing Small Grant (SG 101083) enabling the research and interviews. The authors are grateful to the anonymous reviewers for their helpful comments.

\section{REFERENCES}

Abashin, S.

2017 Migration policies in Russia: laws and debates. in A-L. Heusala and K. Aitamurto (Eds), Migrant workers in Russia: global challenges of the shadow economy in societal transformation, Routledge, Abingdon. 
Adesina, Z., and S. Fayaz

2016 Immigrants'targeted by home office fraudsters'. Available on-line at: http://www.bbc.co.uk/news/ uk-england-london-35723809 (accessed 4 May 2016).

$\mathrm{BBC}$

2013 SouthAfrica police charged with dragging murder. Available on-line at: http://www.bbc.co.uk/ne ws/world-africa-21712710 [accessed May 4, 2016].

2016a Whyis EU struggling with migrants and asylum? Available on-line at: http://www.bbc.co.uk/ne ws/world-europe-24583286 [accessed May 6, 2016].

2016 b Eight reasons Leave won the UK's referendum on the EU. Available on-line at: http://www.bbc.co. uk/news/uk-politics-eu-referendum-36574526 [accessed 6 July 2016].

Beck, A., and Y. Chistyakova

2002 "Crime and policing in Post-Soviet societies: bridging the police/public divide", Policing \& Society, 12(2): 123-137.

Beck, A., and R. Lee

2002 "Attitudes to corruption amongst Russian police officers and trainees", Crime, Law and Social Change, 38(4): 357-372.

Bowling, B., A. Parmar, and C. Phillips

2003 Policing ethnic minority communities. LSE Research on-line. Available on-line at: http://eprints. lse.ac.uk/9576/1/Policing_ethnic_minority_communities_(LSERO).pdf [accessed 4 2017].

Cohen, S.

2011 Folk devils and moral panics (Routledge classics). Available on-line at: https://www.amazon.co.uk/ Devils-Moral-Panics-Routledge-Classics/dp/0415610168 [accessed 6 July 2016].

Cowan, R.

2016 Immigrantstell of forced prostitution and slavery as trafficking gang is jailed. Available on-line at: http://www.theguardian.com/uk/2005/nov/02/immigration.ukcrime (accessed 6 July 2016).

Drury, I.

2016 Criminalconvictions for EU migrants leap by $40 \%$ in five years. Available on-line at: http:// www.dailymail.co.uk/news/article-3450323/Criminal-convictions-EU-migrants-leap-40-five-years700-guilty-week-UK-20-000-foreign-criminals-deported.html [accessed 6 July 2016].

Dugan, E.

2015 Thousandsof children in Britain being forced to live on $£ 1$ a day. Available on-line at: http:// www.independent.co.uk/news/uk/home-news/thousands-of-children-in-britain-being-forced-to-liveon-1-a-day-10292792.html (accessed 6 July 2016).

Endley, B.

2014 Does immigration bring crime to the UK? Available on-line at: http://www.mirror.co.uk/news/amp p3d/immigration-bring-crime-uk-4669746 [accessed 6 July 2016].

Fedirko, N.

2015 "Social protection of migrant workers in Ukraine: striving towards European standards under crisis", Eastern Journal of European Studies, 6(2): 83-112.

Friesendorf, C.

2017 "Police Reform in Ukraine as Institutional Bricolage", Problems of Post-Communism, https://doi. org/10.1080/10758216.2017.1351304.

Hamilton, M.

2015 Law and Border. Available on-line at: http://www.thesun.co.uk/sol/homepage/news/6580063/Viole nt-foreign-criminals-are-entering-the-UK.html [accessed 6 July 2016].

Haughey, C.

2016 Modern Day Slavery Act Review. Available on-line at: https://www.gov.uk/government/uploads/sys tem/uploads/attachment_data/file/542047/2016_07_31_Haughey_Review_of_Modern_Slavery_Act__final_1.0.pdf

Index

2016 Ukraine Demographic Profile 2016. Available on-line at: http://www.indexmundi.com/ukraine/demo graphics_profile.html [accessed September 7, 2017]

Interfax

2016 Sobyanin brief about migrant labour force developments, Available on-line at: forcehttp://www.interfax.ru/moscow/538890 [accessed September 7, 2017]. 
IOM

2017 Survey on migration and human trafficking in Ukraine. Available on-line at: http://www.iom.org. ua/sites/default/files/migration_and_human_trafficking_in_ukraine_eng.pdf [accessed 3 January 2017].

ITV

2016 PM:End Britain's 'something for nothing' benefits system. Available on-line at: http://www.itv.c om/news/update/2016-02-02/pm-britain-will-never-be-part-of-a-european-superstate/ [accessed January 3,2017$]$.

Junger, M.

1990 "Studying ethnic minorities in relation to crime and ethnic discrimination: answer to Bowling", British Journal of Criminology, 30(4): 493-502.

Lassila, J.

2017 "Beyond conjuncture of Russia's national future: Migrants and refugees in Russia's political discourse in 2013 and 2014", in A-L. Heusala and K. Aitamurto (Eds), Migrant workers in Russia: global challenges of the shadow economy in societal transformation, Routledge, Abingdon.

Light, M.

2010 "Policing migration in Soviet and Post-Soviet Moscow", Post-Soviet Affairs, 26(4): $275-313$.

May, T.

2015 Historic law to end Modern Slavery passed. Available on-line at: https:/www.gov.uk/government/ news/historic-law-to-end-modern-slavery-passed (accessed 4 June 2017).

McCarthy, L.A.

2013 "Local-level law enforcement: Muscovities and their uchastkovyy", Post-Soviet Affairs, 30(2-3): 295-225.

Melossi, D.

2000 "Changing representations of the criminal", British Journal of Criminology, 40(2): 296-320. https://doi.org/10.1093/bjc/40.2.296.

2015 Crime, Punishment and Migration, Sage, London.

Ministry of Education and Science

2016 Foreign students in Ukraine. Available on-line at: http://studyinukraine.gov.ua/life-in-ukraine/interna tional-students-in-ukraine/ [accessed June 4, 2017].

Obrazkova, M.

2013 Moscow illegal immigrants also victims of exploitation. Available on-line at: https://www.rbth.com/ politics/2013/08/16/is_moscow_facing_a_slavery_emergency_28965.html (accessed 4 June 2017).

Polese, A.

2014 "Drinking with Vova: an individual entrepreneur between illegality and informality", in J. Morris and A. Polese (Eds), The informal post-socialist economy: embedded practices and livelihoods, Routledge, London.

Radchuk, A.

2016 New risks of labour migration in Ukraine. Available on-line at: https://ru.slovoidilo.ua/2016/06/15/ kolonka/aleksandr-radchuk/jekonomika/v-ekonomicheskom-tupike-novye-riski-trudovoj-migraciidlya-ukrainy (accessed 4 June 2017).

Serduyk, A., and A. Markovska

2012a "Relationship between work migrants and police in the UK, Russia and Ukraine", in Deviant Conduct: materials of the round table discussion, Sociological Association of Ukraine, Kharkiv: 175179.

2012b "Work migrantion", Visnuk Kharkiv State University, Series: Sociological Studies, 999: 131-136.

Shelley, L.

1990 "Policing Soviet Society: The evolution of the state control", Law \& Social Inquiry, 15(3): 479520 .

TI

2010 .Corruption Perceptions Index 2010. Available on-line at: https://www.transparency.org/cpi2010/mul timedia 
Urinboyev, R.

2017 "Migration and transnational informality in post-Soviet societies: Ethnographic study of po rukam ('handshake') experiences of Uzbek migrant workers in Moscow", in A-L. Heusala and K. Aitamurto (Eds), Migrant workers in Russia: global challenges of the shadow economy in societal transformation, Routledge, Abingdon.

Verkhovna Rada of Ukraine

2001 Zakon Ukrainy "Pro Immihratciu" [Law of Ukraine "On Immigration"], No. 2491-III. Available on-line at: http://zakon3.rada.gov.ua/laws/show/2491-14.Ghj [accessed May 4, 2018].

2011 Zakon Ukrainy "Pro pravovyi status inozemtsiv ta osib bez hromadianstva" [Law of Ukraine "On the legal status of foreigners and stateless persons"], No. 3773-VI. Available on-line at: http:// zakon3.rada.gov.ua/laws/show/3773-17.Ghj [accessed May 4, 2018].

Zabyelina, Y.

2017 Between exploitation and expulsion: Labour migration, shadow economy and organised crime. in A-L. Heusala and K. Aitamurto (Ed.), Migrant workers in Russia: global challenges of the shadow economy in societal transformation, Routledge, Abingdon. 